\title{
Феномен самоубийства в России XVIII в. ${ }^{1}$ The Phenomenon of Suicide in Eighteenth-Century Russia
}

\author{
Александр Каменский \\ Национальный исследовательский университет - Высшая школа экономики
}

Aleksandr Kamenskii

National Research University - Higher School of Economics

akamenskii@hse.ru

\begin{abstract}
:
The history of suicide in Russia, especially prior to the nineteenth century, remains understudied. While in most European countries the process of decriminalization and secularization of suicide was underway, in Russia, with the introduction of the Military Article of 1715, it was formally criminalized. On the basis of the study of more than 350 newly examined archival cases, this article examines how the transfer of suicide investigations to secular authorities also entailed secularization, while the peculiarities of the Russian judicial and investigative system, as well as lacunae in the legislation, actually led to the gradual decriminalization of suicide. At the same time, although among Russians, as well as among other peoples, a number of superstitions were associated with suicide, there is no evidence in the archival documents studied in this article of a particularly emotional perception of suicide. The phenomenon of suicide in eighteenth-century Russia, when compared to early modern Europe, did not have any significant, fundamental differences. However, the features of the Russian judicialinvestigative system made this phenomenon less public, less visible and less significant for public consciousness.
\end{abstract}

Ключевые слова:

История самоубийств, декриминализация, секуляризация, наказание тела, общественное сознание, социальная история России XVIII века

Keywords:

History of suicide, decriminalization, secularization, punishment of the body, public consciousness, social history of eighteenth-century Russia

\section{Христос воскресе.}

Во имя отца и сына и святаго духа аминь.

Се аз раб божий Александр Иванов сын Рубцов сим изустно объявляю и от родителя моего Ивана Матвеевича и от родительницы моей Агрипины Даниловны и от всех сродников прошу прощения. А ныне вас прошу, чтоб на сем свете воспамянуть душу мою грешную. В начале отца моего духовного Петра Васильевича и сестры моей родной Наталья Ивановны, и зятя Степана Ивановича, и всех моих сродников и присных моих, кои мя знали, то прошу упомянуть елико согрешил пред вами. Аще же, когда от о[т]ца моего родился, до кончины живота ево находился при нем. Когда же отца моего в 727-м году не стало, токмо я остался после ево в младых летех, однако жил все благополучи. А в 740м году в апреле месяце учинилось мне великое несчастие, что жестокая

\footnotetext{
${ }^{1}$ Исследование выполнено в рамках программы фундаментальных исследований Национального исследовательского университета “Высшая школа экономики” в 2020 г.
} 
ко мне в ногу скорбь приключилася, от которой болезни по нынешней 760 год едва находился, что всего жития своего отвратился. А в нынешней же год пришел ко мне, что несносно мне: пришел в великое убожество, все меня оставили и никто мне способа не учинил, только что я напрасно жизнь свою провождал. Ныне пришло мне нестерпимо, что при старости ни обмыть, ни обшить, но и о пищи себе промыслить за скорбию не мог и едва ногами движением чрез великую мочь имел, от чего уже я нестерпимой болезни и бросился в воду, воспомянув дни жития моего скончался, аминь. Более писать не имею, токмо сами изволите знать, ежели ж хозяин потребует денег, то только доплатить один рубль, а осталось у него кафтан, да белой тулуп, постеля с кабинетом, что в нем имеется, да Юстиц-колегии у сторожа Петра Васильева епанча в закладе в рубле в пятидесят копейках.

Это по-своему уникальное письмецо, написал на осьмушке бумаги покончивший с собой в 176о г. подканцелярист московской конторы Юстиц-коллегии Александр Рубцов. ${ }^{2}$ Сенсации оно не произвело, никакого следствия о случившемся, судя по всему, не производилось и неизвестно, было ли обнаружено и захоронено тело покойного. Кажется, чиновниками коллегии случившееся было воспринято лишь как досадное, неприятное происшествие.

Самоубийство, то есть добровольный уход из жизни - один из видов смерти, и, поскольку человеку свойственно дорожить жизнью, поскольку в христианской культуре жизнь - это дар божий, в европейской гуманистической традиции жизнь это высшая ценность и поскольку в силу этого люди, как правило, испытывают страх перед смертью, ${ }^{3}$ для большинства самоубийство - это нечто загадочное, пугающее и отталкивающее, хотя иногда и с романтическим налетом. ${ }^{4}$ Вместе с тем самоубийство - это социальный и культурный феномен, существовавший всегда и везде. Более того, в исторической памяти многих народов присутствуют случаи легендарных и героических самоубийств, в том числе массовых, как, например, описанное Иосифом Флавием самоубийство защитников Массады во время первой Иудейской войны, самоубийство тевтонских женщин в 102 г. после поражения в битве при Аквах Секстиевых или самоубийство жителей Бали в 1906 г. на глазах голландских оккупантов. ${ }^{5}$ Известны своего рода эпидемии самоубийств в среде русской

\footnotetext{
${ }^{2}$ Российский государственный архив древних актов (РГАДА), Ф. 282. Юстиц-коллегия. Оп. 1. Д. 8699. Л. 1-4. (Rossiiskii gosudarstvennyi arkhiv drevnikh aktov (RGADA), F. 282. Op. 1. D. 8699. L. 1-4).

${ }^{3}$ Речь в данном случае идет прежде всего об отношении к смерти в европейской культуре, имеющей иудео-христианские корни. Во многих других культурах отношение к смерти, как известно, иное.

${ }^{4}$ В аннотации к недавно вышедшему сборнику статей о самоубийстве говорится: “Самоубийство - это загадочный феномен [...] Культуры, в которых высок уровень самоубийств, не обязательно имеют много общего, и не только душевная болезнь вроде депрессии непременно ведет к самоубийству. Короче говоря, несмотря на статистику, на индивидуальном уровне самоубийство непредсказуемо. Основной вывод этого сборника в том, что самоубийство не следует понимать, как особый вид патологического поведения, но как форму человеческого действия. Как таковое оно всегда зависит от решения, принятого индивидом в культурном, этическом и социо-экономическом контексте, но контекст, не полностью определяет решение. В нем также доказывается, что культурные нарративы о самоубийстве имеют проблематизирующую двойную функцию: помимо снабжения общества пониманием смысла самоубийства, они представляют собой проект, изображающий самоубийство как способ решения человеческих проблем." См. Marja-Liisa Honkasalo and Miira Tuominen, eds., Culture, Suicide, and the Human Condition (New York: Berghahn Books, 2014).

${ }^{5}$ С такого рода самоубийствами связано понятие “мортилатрия," которым обозначают культ смерти, совершенной во имя какой-либо высокой цели.
} 
эмиграции второй половины 1920-х гг., ${ }^{6}$ немцев и японцев в конце Второй мировой войны, истории массовых самоубийств членов разных религиозных сект, начиная с русских старообрядцев и т. д. Мы знаем, что такое харакири в японской культуре, а в современном мире хорошо известно слово “шахид."

Известно также, что в Новое время философское осмысление жизни и смерти неоднократно порождало своеобразную моду на самоубийства, как, к примеру, в Англии второй половины XVIII века ${ }^{8}$ или в России начала XX-го. Соответственно, самоубийству посвящено множество философских трактатов, а также трудов психиатров, психологов и социологов, начиная с классической работы Э. Дюркгейма, изданной по-русски уже в 1912 г. ${ }^{9}$ Также, поскольку речь идет о социальном и культурном феномене, он является предметом изучения и в рамках исторической науки.

История самоубийств не принадлежит к числу “магистральных" направлений исторической науки, однако ее историография достаточно обширна и включает десятки статей и ряд крупных монографических исследований. ${ }^{10}$ Интерес к этой проблематике стал расти в 1980-е гг. в связи, с одной стороны, с изучением истории смерти, а, с другой, обращением историков к судебно-следственной документации как источнику по истории повседневности и внутреннему миру людей прошлого.

\footnotetext{
${ }^{6}$ Откликом на нее был труд Н. А. Бердяева О самоубийстве, в котором он писал, что “Самоубийство вызывает жуткое, почти сверхъестественное чувство, как нарушение божеских и человеческих законов, как насилие не только над жизнью, но и над смертью [...] Самоубийство совершается в особую, исключительную минуту жизни, когда черные волны заливают душу и теряется всякий луч надежды. Психология самоубийства есть прежде всего психология безнадежности." Н. А. Бердяев, O самоубийстве (Париж: YMCA Press. 1931), 6, 10. (N. A. Bediaev, O samoubiistve (Paris: YMCA Press, 1931), $6,10)$.

${ }^{7}$ В одной из советских пьес 1920-х гг. гражданам, признанным бесполезными для дела революции, предлагалось добровольно уйти из жизни, т.е. покончить с собой в течение 24 часов. См. С. Ю. Малышева, “На миру красна:" инструментализация смерти в Советской России (Москва: Новый хронограф, 2019), 121. (S. Iu. Malysheva, "Na miru krasna:" instrumentalizatsiia smerti v Sovetskoi Rossii (Moscow: Novii khronograf, 2019), 121). Здесь же образцы героизации самоубийства (125-126), сведения о самоубийствах среди коммунистов в 1920-е гг. и об изменении отношения к этому феномену советских властей (134-140).

8 Лишь за один месяц - октябрь 1789 г. - английские газеты сообщили о 53 случаях самоубийств. Ю. М. Лотман, ссылаясь на Письма русского путешественника Н. М. Карамзина, отмечал, что “Представление о самоубийстве как специфической черте 'английского поведения' было широко распространено.” При этом, Н. Н. Бантыш-Каменский, также писавший о самоубийстве, как об “английской болезни," в отличие от Карамзина, связывал это не с особенностями климата, а с французским вольнодумством. См. Ю. М. Лотман, Очерки по русской культуре XVIII века (Москва: Языки русской культуры, 200o), 312-313. (Iu. M. Lotman, Ocherki po russkoi kul'ture XVIII veka (Moscow: Iazyki russkoi kul'tury, 2000), 312-313). С конца XVII и на протяжении всего XVIII столетия самоубийство было в Англии объектом пристального внимания литераторов, публицистов, проповедников и философов и даже предметом дебатов в лондонских дискуссионных обществах. См. D. T. Andrew, Aristocratic Vice: The Attack on Duelling, Suicide, Adultery, and Gambling in Eighteenth-Century England (New Haven: Yale University Press, 2013), 83-126.

9 Эмиль Дюркгейм, Самоубийство: социологический этюд (Санкт-Петербург: Издание Н. П. Карбасникова, 1912). (Émile Durkheim, Samoubiistvo: sotsiologicheskii etiud (St. Petersburg: Izdanie N. P. Karbasnikova, 1912).

${ }^{10}$ См., например, Alexander Murray, Suicide in the Middle Ages, 2 vols. (Oxford: Oxford University Press, 1998-2000); Michael MacDonald and Terence Murphy, Sleepless Souls: Suicide in Early Modern England. (Oxford: Clarendon Press, 1990); Robert Allan Houston, Punishing the Dead? Suicide, Lordship, and Community in Britain, 1500-1830 (Oxford: Oxford University Press, 2010); Georges Minois, History of Suicide: Voluntary Death in Western Culture (Baltimore: Johns Hopkins University Press, 1999); Jeffrey Watt, ed. From Sin to Insanity: Suicide in Early Modern Europe (Ithaca, NY: Cornell University Press, 2004).
} 
“Изучая самоубийства, - пишет американский историк Дж. Уатт, - можно узнать не только о самом самоубийстве, но и... о преобладающих нравах и мнениях. Действительно, самоубийство и отношение к нему открывают бесценное окно к коллективной ментальности определенного общества."'1

Что касается истории самоубийств в России, то она остается мало изученной. Обращавшиеся к ней немногочисленные исследователи концентрировали свое внимание преимущественно на XIX - XX вв. и на культурологических аспектах этого явления. ${ }^{12}$ Относительно же XVIII столетия, помимо простых упоминаний о нескольких конкретных случаях, а также работ об известных самоубийцах - И. М. Опочинине и М. В. Сушкове - интеллектуалах, оставивших пространные объяснения своего поступка, ${ }^{13}$ единственным специально посвященным этому периоду исследованием, хотя и в рамках более широкого хронологического контекста, является книга американской исследовательницы Сьюзен Моррисей. ${ }^{14}$ Историк подробно остановилась на характеристике соответствующего законодательства, причинах самоубийств и отношении к ним государства и общества. Ее книга содержит немало интересных наблюдений, однако сведения о примерно сотне случаев, на которых она основывает свои выводы и почерпнутых ею как из опубликованных, так и архивных источников, относятся к последней четверти XVIII столетия и лишь к самоубийствам, произошедшим в Москве и Петербурге.

В моей вышедшей в 2006 г. книге о городской повседневности описаны три случая самоубийства. Работая над этой книгой и обнаружив в литературе лишь несколько упоминаний, я счел, что, наверное, это явление для России XVIII века было редким. Попытавшись объяснить этот, как теперь выяснилось мнимый факт, я предположил, что это было связано с низким уровнем интеллектуального развития основной массы российского населения, поскольку, как я полагал, самоубийство подразумевает определенный уровень рефлексии, оценки собственной жизни. ${ }^{15}$ Очевидная

\footnotetext{
${ }^{11}$ Watt, "Introduction," From Sin to Insanity, 2.

${ }^{12}$ А. Лярский, "Простите, дорогие папа и мама:" родители, дети и борьба с подростковыми самоубийствами в России конца XIX - начала XX века (Санкт-Петербург: Крига, Победа, 2017). (А. Liarskii, "Prostite, dorogie papa i mama: roditeli, deti i bor'ba s porostkovymi samoubiistvami v Rossii XIXnachala XX veka (St. Petersburg: Kriga, Pobeda, 2017); И. Паперно, Самоубийство как культурный институm (Москва: Новое литературное обозрение, 1999). (I. Paperno, Samoubiistvo kak kul'turnyi institut (Moscow: Novoe literaturnoe obozrenie, 1999); И. Л. Полотовская, Смерть и самоубийство: Россия и мир: историко-культурологическое развитие проблематики с древнейших времен до наших дней. (Санкт-Петербург: Дмитрий Буланин, 2010). (I. L. Polotovskaia, Smert'i samoubiistvo: Rossiia i mir: istoriko-kul'turologicheskoe razvitie problematiki s drevneishikh vremen do nashikh dnei (St. Petersburg: Dmitrii Bulanin, 2010); Г. Ш. Чхартишвили, Писатель и самоубийство. (Москва: Новое литературное обозрение, 2001). (G. Sh. Chkhartishvili, Pisatel' i samoubiistvo (Moscow: Novoe literaturnoe obozrenie, 2001); K. M. Pinnow, Lost to the Collective: Suicide and the Promise of Soviet Socialism, 1921- 1929 (Ithaca: Cornell University Press, 2010).

${ }^{13}$ См. М. Г. Фраанье, “Прощальные письма М. В. Сушкова: О проблеме самоубийств в русской культуре конца XVIII века”, XVIII век, сб. 19 (Санкт-Петербург: Наука, 1995), 147-167. (M. G. Fraan'e, "Proshal'nye pis'ma M.V. Sushkova: o probleme samoubiistv v russkoi kul'ture kontsa XVIII veka," XVIII vek, sb. 19 (St. Petersburg: Nauka, 1995), 147-167); Е. А. Ермолин и А. А. Севастьянова, Воспламененные к отечеству любовью (Ярославль: Верх.-Волж. кн. изд-во, 1990), 37-39. (Е. A. Ermolin і А. А. Sevast'ianova, Vosplamenennye k otechestvu liubov'iu (Iaroslavl': Verkh.-Volzh. kn. izd-vo, 199o), 37-39); Л. Н. Трефолев, “Предсмертное завещание русского атеиста," Исторический вестник, т. 11 (1883), 224-226. (L. N. Trefolev, "Predsmertnoe zaveshchanie russkogo ateista," Istoricheskii vestnik, t. 11 (1883), 224-226).

${ }^{14}$ S. K. Morrissey, Suicide and the Body Politic in Imperial Russia. (Cambridge: Cambridge University Press, 2006).

${ }^{15}$ А. Б. Каменский, Повседневность русских городских обывателей. Исторические анекдоты из провинциальной жизни XVIII века (Москва: РГГУ, 2006), 221-229. (A. B. Kamenskii, Povsednevnost'
} 
голословность этого утверждения побудила специально заняться этой проблематикой.

Как расследовались и как трактовались в России XVIII в. случаи самоубийств? Как воспринимали самоубийц в русском обществе? Менялось ли это восприятие на протяжении XVIII века и отражалось ли это на судебной практике? Какова была реакция людей, непосредственно сталкивавшихся с этим явлением? Наконец, в какой степени российские практики были схожи или, напротив, отличались от принятых в других странах этого времени? Таковы основные вопросы, на которые делается попытка найти ответы в этой статье.

$\stackrel{*}{* *}$

В основе настоящего исследования - документы Российского государственного архива древних актов, в фондах которого на сегодняшний день выявлено около 350 кейсов, которые дают возможность утверждать, что самоубийство в России XVIII века было явлением достаточно распространенным. При этом нет сомнения, что продолжение архивных разысканий может значительно пополнить эти данные, но, во-первых, пытаться выявить все зафиксированные в документах случаи, на мой взгляд, нет смысла, а во-вторых, и тогда полной статистики самоубийств за столетие у нас не будет, поскольку какие-то документы не сохранились, а какие-то случаи по тем или иным причинам не были задокументированы. ${ }^{16}$ Тем не менее, полученная выборка представляется вполне репрезентативной. Во-первых, она охватывает практически все столетие: самый ранний зафиксированный случай относится к 1710 г., самый поздний - к 1796. Во-вторых, в ней представлены все социальные группы населения России этого времени. В-третьих, у нее широкая география: помимо Москвы и Петербурга это и Вятская и Орловская провинции, Верхотурье и Тамбовская губерния, и. т. д.

Однако возможности каких-либо подсчетов, которые можно сделать на основе этой базы данных, ограничены, что связано с использованными архивными фондами. Примерно половина зафиксированных кейсов - это данные из фондов местных учреждений - провинциальных и воеводских канцелярий, а также городовых магистратов. Чем было обусловлено обращение именно к этим фондам, будет объяснено ниже. Здесь же необходимо сказать, что степень их сохранности, как и качество научно-справочного аппарата, по которому проводилось выявление документов, различно. В некоторых фондах, насчитывающих лишь десятки дел, удалось выявить по несколько кейсов, в то время как в некоторых хорошо сохранившихся фондах, насчитывающих тысячи единиц хранения, документов о самоубийствах не обнаружено вовсе, что, конечно же, не означает, что в соответствующем регионе подобные происшествия не случались. Несколько кейсов выявлено также в документах Сыскного приказа. Другая половина собранных данных - это информация из еженедельных отчетов о происшествиях в столицах петербургского и московского губернаторов начала 1770-х - 1790-х годов. При этом, судя по этим отчетам, петербургские губернаторы педантично фиксировали все

russkikh gorodskikh obyvatelei. Istoricheskie anekdoty iz provintsial'noi zhizni XVIII veka (Moscow: RGGU, 2006), 221-229).

${ }^{16}$ Статистику за XIX век см. в Я. Гилинский, Социология преступности, наркотизма, проституции, самоубийств и других “отклонений” (Санкт-Петербург: Юридический центр Пресс, 2004), 168. (Iа. Gilinskii. Sotsiologiia prestupnosti, narkotizma, prostitutsii, samoubiistv i drugikh “otklonenii” (St. Petersburg: Iuridicheskii tsentr Press, 2004), 168). 
случаи самоубийств и считали необходимым доносить об этом императрице, а московские сообщали лишь о наиболее скандальных. Таким образом, случаев по Петербургу и его окрестностям довольно много, но это вовсе не означает, что столичные жители кончали с собой чаще, чем москвичи или обитатели других регионов. Стоит также добавить, что фонды местных учреждений XVIII в. изобилуют делами об обнаружении мертвых тел неизвестных мужчин и женщин, а также об освидетельствовании скоропостижно умерших; в докладах же петербургских губернаторов содержится множество сведений о едва ли не ежедневно вылавливаемых из Невы, Мойки и Фонтанки трупов неизвестных утопленников, по одежде которых определяли лишь их социальную принадлежность. Нельзя исключать, что и среди них были самоубийцы, но установить это, как правило, невозможно.

С точки зрения социальной принадлежности среди выявленных самоубийц больше всего крестьян, ${ }^{17}$ что не означает, что именно они были более всего склонны к суициду. Объясняется это, прежде всего тем, что крестьяне вообще составляли основную массу населения. Вместе с тем это опровергает процитированное мною в книге 2006 г. высказывание Г. Ш. Чхартишвили о том, что “интеллектуалы убивают себя в десять раз чаще, чем люди малообразованные - именно потому, что образованность и связанная с нею материальная обеспеченность... способствует обострению индивидуализма." 8

Большинство русских самоубийц XVIII в. - мужчины (более 70\%), и в этом отношении Россия не отличалась от других стран Европы раннего Нового времени. Дж. Уатт отмечает, что “практически во всех обществах эпохи модерна мужчины составляют намного большую часть тех, кто кончал с собой.” По его мнению, “с исчезновением религиозных средств устрашения мужчины стали более склонны к самоубийству, поскольку, стремясь к достижению экономического и политического успеха, они чаще испытывали разочарование." в предшествующие столетия женщины кончали с собой чаще или хотя бы столь же часто, как мужчины, ${ }^{20}$ однако важнее появление, по мнению Уатта, новых, чисто мужских поводов к самоубийству. Выяснить, насколько это наблюдение справедливо для России XVIII в., также одна из задач данной работы.

C начала XVIII в. самоубийства в России, как и иные формы девиантного поведения постепенно переходили из ведения церковных в ведение светских властей, ${ }^{21}$ что было закреплено в петровском законодательстве. Артикул воинский 1715 г. однозначно квалифицировал самоубийство как уголовное преступление и предписывал:

Ежели кто сам себя убьет, то надлежит палачу тело его в безчестное место отволочь и закопать, волоча прежде по улицам или обозу.

\footnotetext{
${ }^{17}$ Крестьяне (помещичьи, монастырские, государственные), дворовые, солдаты, казаки и ямщики составляют немногим менее $85 \%$ всех попавших в базу.

${ }^{18}$ Г. Чхартишвили, Писатель и самоубийство, 150. (G. Chkhartishvili, Pisatel' i samoubiistvo, 150).

${ }^{19}$ Watt, "Introduction," From Sin to Insanity, 7.

${ }^{20}$ По данным А. Мюррея (Murray, Suicide in the Middle Ages, vol. 1, vii) в средние века соотношение мужских и женских самоубийств составляло $74 \%$ к 26\%, однако К. Каллаган утверждает, что эта статистика не точна, поскольку источники фиксировали не все случаи женских самоубийств. См. С. G. Callaghan, "Seven Shillings and a Penny: Female Suicide in Late Medieval England," Medieval Feminist Forum, 43:1 (2007): 89-91).

${ }^{21} \mathrm{O}$ том, является ли самоубийство девиацией см. Гилинский, Социология преступности, 159-16о. (Gilinskii, Sotsiologiia prestupnosti, 159-160).
} 
Толкование. А ежели кто учинил в безпамятстве, болезни, в меленхолии, то оное тело в особливом, но не в безчестном месте похоронить. И того ради должно, что пока такой самоубийца погребен будет, чтоб судьи наперед о обстоятельстве и притчинах подлинно уведомились, и чрез приговор определили б, каким образом его погребсти.

Ежели салдат поиман будет в самом деле, что хотел себя сам убить, и в том ему помешали, и того исполнить не мог, а учинит то от мучения и досады, чтоб более не жить, или в безпамятстве и за стыдом, оный по мнению учителей прав с безчестием от полку отогнан быть имеет. А ежели ж кроме вышепомянутых притчин сие учинил, онаго казнить смертию” (Глава 19, Артикул 164).

С. Моррисей отмечает, что “особые причины, по которым самоубийство было включено в уголовное право, остаются неясными, но конечно был важен контекст продолжавшейся борьбы со староверами с учетом их массового мученичества."2 Соглашаясь с этим, стоит добавить, что формирование в результате петровских реформ регулярного государства, во-первых, в принципе предполагало расширение его функций по контролю за каждым подданным, а во-вторых, ставило перед ним цель сбережения жизни всякого человека, необходимой для исправной работы государственного механизма. Добровольный уход из жизни воспринимался теперь не только как нарушение божественных заповедей, но и как уклонение от выполнения долга по отношению к государству, как нарушение монопольного права государства на распоряжение жизнью и телом человека.

Однако эти объяснения далеко не достаточны. Более того, они представляют собой характерный пример реконструкции историком намерений исторического персонажа на основе знаний о том, что произошло после совершенного им действия. Между тем, Артикул воинский создавался прежде всего, как законодательный акт, предназначенный для военнослужащих. Самоубийство солдата фактически было равноценно дезертирству и нет никаких оснований предполагать, что Петр изначально собирался распространить действие норм Артикула и на гражданское население, как это произошло на практике. ${ }^{23}$ Причины появления в Артикуле воинском статей о самоубийстве следует искать в истории этого законодательного акта.

По заключению Д. О. Серова, “несмотря на всю работу российского законодателя /Петра I - А.К./ над проектом Артикула воинского, необходимо признать, что этот законодательный акт остался в основе своей компиляцией западноевропейских уставов и инструкций.” Его составитель Э. Кромпейн использовал, как принято считать, “акты шведского, датского и австрийского военного законодательства последней трети XVI - XVII вв., особенно широко - нормы шведского Воинского артикула редакции 1683 г. (Caroli XI, Königs in Schweden, Kriegs-Articel, de an. 1683),” в то время как в “Кратком изображении процессов,” печатавшимся вместе с Артикулом

\footnotetext{
${ }^{22}$ Morrissey, Suicide and the Body Politic, 43.

${ }^{23}$ В 1754 г., когда Сыскной приказ, ссылаясь на нормы Артикула воинского, отправил на утверждение в Юстиц-коллегию смертный приговор за изнасилование, вышестоящая инстанция отвечала, что действие артикула распространяется только на военнослужащих, а гражданских следует судить по Уложению 1649 г. (РГАДА, Ф. 372. оп. 1. д. 3013) (RGADA, F. 372. op. 1. d. 3013).
} 
воинским, “использовались в первую очередь акты военного законодательства Саксонии, а также австрийские ... и датские военно-процессуальные акты.”24

Именно с источниками Артикула воинского связаны и особенности приведенного выше отрывка, в котором самоубийство трактуется в качестве уголовного преступления, как это имело место в европейском праве по крайней мере с XIII в. Соответственно, тело преступника не только не могло удостоиться обычного обряда погребения в соответствии с отношением к этому явлению христианства и постановлениями церкви, но подлежало наказанию. В некоторых европейских странах его сжигали, в других подвешивали за ноги, а Саксонское зерцало XIV в. предписывало предварительно протащить его по земле, как поступали с телами казненных преступников во многих странах эпохи Средневековья. Ряд средневековых кодексов содержал и нормы наказания за попытки самоубийства, которые в шведском праве появились к концу XVII в. Вместе с тем, одновременно с криминализацией самоубийства с XIII в., в европейском законодательстве под влиянием Римского права постепенно формируются и нормы, смягчающие наказание за преступления, совершенные сумасшедшими. ${ }^{25}$ Установление факта наличия смягчающих обстоятельств было непосредственно связано с принятием решения о посмертном наказании или не наказании самоубийцы, которое выражалось в вынесении соответствующего решения о форме его погребения (в некоторых странах самоубийц, покончивших с собой из-за болезни или сумасшествия, разрешалось хоронить в церковной ограде, но без отпевания и нередко ранним утром или поздним вечером). Такое решение выносилось либо в судебном заседании, как, например, в Швеции, где самоубийца посмертно представал перед судом в качестве обвиняемого, ${ }^{26}$ либо это была прерогатива церковных властей, которые рассматривали соответствующие прошения родственников или знакомых покойного и выдавали соответствующее разрешение на погребение, как это имело место, например, в Англии. ${ }^{27}$

Именно эти нормы воспроизводил Артикул воинский и, таким образом, можно заключить, что криминализация самоубийства в русском праве, то есть трактовка его как уголовно наказуемого деяния была результатом не столько осознанных и целенаправленных действий законодателя, сколько в определенной мере результатом случайности: самоубийство оказалось “в одном пакете” с другими воинскими преступлениями, заимствованными из западноевропейских кодексов. Можно при этом предположить, что, если бы попытки Петра I по созданию нового

\footnotetext{
${ }^{24}$ Д. О. Серов, “Забытые редакции Артикула воинского и 'Краткого изображения процессов или судебных тяжеб’ (из истории кодификации военного законодательства России XVIII в.), Lex russica, no. 2 (2013): 113-121. (D. O. Serov, "Zabytye redaktsii Artikula voinskogo i 'Kratkogo izobrazheniia protsessov ili sudebnykh tiazheb' (iz istorii kodofikatsii voennogo zakonodatel'stva Rossii XVIII v.)," Lex russica, no.2 (2013): 113-121). Стоит, однако, заметить, что в 167 артикуле главы 20 Артикула воинского, где речь идет об изнасиловании, имеется ссылка на "саксонские права."

${ }^{25}$ По Кодексу императора Адриана (II век н. э.) солдату, совершившему неудавшуюся попытку суицида, отрубали голову, “...если только причиной тому не были невыносимое горе, болезнь, скорбь или иная подобная причина,” а также “усталость от жизни, безумие или стыд.” См. Сергей Жданов и Настя Травкина, “Из истории суицидальной мысли," Батенька, да вы трансформер, 20.4.2017, https://batenka.ru/explore/science/suic-idea/. (Sergei Zhdanov i Nastia Travkina, "Iz istorii suitsidal'noi mysli," Baten'ka, da vy transformer, 20.4.2017, https://batenka.ru/explore/science/suic-idea/).

${ }^{26}$ Краткий очерк истории эволюции норм европейского права о самоубийстве см. Riikka Miettinen, Suicide, Law, and Community in Early Modern Sweden (London: Palgrave Macmillan, 2019), 47-56.

${ }^{27}$ P. S. Seaver, "Suicide and the Vicar General in London: A Mystery Solved?," From Sin to Insanity, 25-47.
} 
гражданского законодательства увенчались успехом, нормы, касающиеся самоубийств, нашли бы отражение и в нем, но этого не произошло. ${ }^{28}$

Таким образом, с принятием Артикула воинского самоубийство, до этого осуждавшееся как тяжкий грех с соответствующими последствиями для тела покойного, теперь стало считаться преступлением и из ведения церкви перешло в ведение светских властей, хотя погребение по-прежнему, как мы увидим, до определенной степени оставалось прерогативой церкви - по крайней мере, в том, что и светскими властями осуществлялось по церковным правилам. В апреле 1722 г. Петр I наложил резолюции на вопросы Синода, касавшиеся, в частности, разграничения полномочий светского и церковного суда в части расследования преступлений, но самоубийство там не упоминалось, именно потому что в церковном праве не считалось преступлением. ${ }^{29}$ Отныне расследование самоубийств стало сферой исключительно светской власти. Этим и обусловлено обращение в данной статье к архивным фондам административных органов, обладавшим также судебными функциями.

В то время как в России введение в действие воспроизводившего нормы европейского права Артикула воинского означало криминализацию самоубийства, в самой Европе на протяжении XVIII столетия шел постепенный процесс его декриминализации, сопровождавшийся и изменением отношения общества к этому явлению. Ш. Монтескье, посвятивший самоубийству 76-е письмо своих "Персидских писем,” писал: “В Европе законы против самоубийц беспощадны. Их, так сказать, предают смерти вторично: тела их с позором волокут по улицам, самоубийц объявляют негодяями, отчуждают их имущество. Мне кажется, Иббен, что эти законы крайне несправедливы. Если я удручен горем, нищетою, презрением, почему мешают мне положить конец всем мукам и жестоко лишают меня лекарства, которым я располагаю?”3о О бессмысленности посмертного наказания самоубийц писал и Ч. Беккариа: “это вина перед Богом, и он карает за нее после смерти. Перед людьми же самоубийство преступлением не является, поскольку наказанию за него подвергается не виновник, а его семья. Если же мне кто-либо возразит, что это наказание тем не менее может удержать человека от самоубийства, то я отвечу: кто спокойно отказывается от блага жизни, кто ненавидит свое земное существование настолько, что предпочитает ему скорбную вечность, того должны оставлять безразличным менее действенные и более отдаленные соображения о детях или о родителях." ${ }^{1}$

Что касается декриминализации самоубийства, то пионером в этом процессе, как кажется, была Голландия, где уже с конца XVI в. наказывать стали только тела самоубийц, совершивших уголовное преступление и покончивших с собой до вынесения судебного приговора или до его исполнения, причем интересно, что

\footnotetext{
28 Поскольку, как известно, проект уложения 1723-1726 гг. также составлялся с активным использованием шведского и датского законодательства, высока вероятность, что и в гражданском законодательстве были бы воспроизведены те же нормы.

${ }^{29}$ Полное собрание законов Российской империи, т. 6 (Санкт-Петербург: Типография II Отделения Собственнй Его Императорскаго Величества Канцелярии, 1830), № 3963, 650-652. (Polnoe sobranie zakonov Rossiiskoi imperii, t. 6 (St. Petersburg: Tipografiia II Otdeleniia Sobstvenii Ego Imperatorskago Velichestva Kantseliarii, 1830), no. 3963, 650-652).

$3^{30}$ Шарль Луи Монтескье, Персидские письма (Москва: Кучково Поле, 2002),128-129. (Charles Louis Montesquieu, Persidskie pis'ma (Moscow: Kuchkovo Pole, 2002), 128-129).

${ }^{31}$ Чезаре Беккариа, О преступлениях и наказаниях (Москва: Инфра-М, 2004), 139. (Cesare Beccaria, O prestupleniiakh i nakazaniiakh (Moscow: Infra-M, 2004), 139).
} 
произошло это в процессе вытеснения обычного права писанным. ${ }^{32}$ В этой связи не случайно Дж. Уатт отмечает, что при сохранении предписывавшихся законом практик погребения самоубийц постепенное исчезновение наказания их тел не было результатом критики этого явления просветителями, но началось задолго до их появления, а их взгляды были выражением шедшего процесса осознания, что наказание тела и имущества самоубийцы наносит ущерб живым. ${ }^{33}$

Важно также, что в Европе раннего Нового времени, помимо осуждения самоубийства с религиозной точки зрения, оно воспринималось, как угроза стабильности семьи, сообщества (community), к которому принадлежал самоубийца, и общества в целом. Соответственно, самоубийство оказывается тесно связанным с понятием чести, и именно поэтому родственники покойного, стараясь избежать позора, пытались подкупить выносивших приговор судей и чиновников. Иначе говоря, процесс декриминализации самоубийства сопровождался его секуляризацией.

Сочинение Ч. Беккариа О преступлениях и наказаниях стало одним из основных источников Наказа Екатерины II Уложенной комиссии. Персидские письма Монтескье впервые были опубликованы по-русски в 1789 г. $^{34}$ Но оказали ли их идеи какое-либо влияние на восприятие самоубийства русским обществом?

Известное высказывание М. Е. Салтыкова-Щедрина о том, что “строгость российских законов смягчается необязательностью их исполнения,” наряду с широко распространенным представлением об отсутствии у россиян правового сознания, как кажется, находится в определенном противоречии с результатами исторических исследований последних лет, демонстрирующих, что судебные органы империи в целом стремились к строгому соблюдению норм законодательства и, скорее его несовершенство, как и неразвитость самой судебной системы, открывали возможности избежать наказания и порождали вариативность судебных решений. ${ }^{35}$ Вместе с тем, как отмечает Ребекка Проберт, “судьи и сами находились под влиянием социальных норм, и были в состоянии влиять на них: их приговоры были такой же частью социального дискурса того времени, как дневники и художественная литература, на которой основывают свои исследования историки эмоций." 36

До екатерининской реформы 1775 г. в России, как уже говорилось, не существовало судебной системы, отделенной от административных органов власти, как не существовало и регулярной полиции, охватывавшей всю страну. Соответственно в провинции расследованием дел о самоубийствах занимались местные учреждения губернские, провинциальные, воеводские канцелярии и городовые магистраты. После 1775 г., как свидетельствуют донесения губернаторов последней четверти века, эти дела также оказались в ведении не судебных, а полицейских органов. Особенности организации следствия и судопроизводства в России до судебной реформы 1775 г., как будет показано ниже, определенным образом скорректировали

\footnotetext{
${ }^{32}$ Machiel Bosman, "The Judicial Treatment of Suicide in Amsterdam," From Sin to Insanity, 9-24.

${ }^{33}$ Watt, "Introduction," From Sin to Insanity, 5.

${ }^{34}$ В. Г. Дмитриев, “"Персидские письма' в России,” в В. Г. Дмитриев, По стране литературии: Этюды (Москва: Московский рабочий, 1987), 107-111. (V. G. Dmitriev, “"Persidkie pis'ma' v Rossii,” v V. G. Dmitriev, Po strane literaturii: Etiudy (Moscow: Moskovskii rabochii, 1987), 107-111).

${ }^{35}$ См., например, N. S. Kollmann, Crime and Punishment in Early Modern Russia (Cambridge: Cambridge University Press, 2012).

${ }^{36}$ Rebecca Probert, "Control over Marriage in England and Wales, 1753-1823: The Clandestine Marriages Act of 1753 in Context," Law and History Review, 27:2 (Summer 2009), 416.
} 
практику применения норм Артикула воинского к самоубийцам. При этом в применявшихся административными органами практиках отразилось, по сути, отношение власти к этому феномену.

Дело по расследованию факта самоубийства возникало, как правило, по доношению в местный орган власти выборных - старост, десятских, пятидесятских или сотских. В своем доношении они сообщали и о результатах первоначального осмотра тела, проведенного ими при свидетелях, среди которых нередко был и местный священник. Однако, как и в других странах, властям необходимо было самим официально установить факт самоубийства, исключив насильственный, криминальный характер смерти (с этой же целью проводилось освидетельствование и всех скоропостижно умерших). Поэтому учреждение - провинциальная или воеводская канцелярия или городовой магистрат, получив доношение, посылали на место какого-то мелкого чиновника, а иногда и вовсе солдата, который, также в присутствии свидетелей, проводил повторный осмотр тела, представлял соответствующий рапорт и иногда тут же либо давал распоряжения о погребении, либо сам его организовывал - в зависимости от того, что предписывала данная ему инструкция. В некоторых местностях канцелярии требовали привезти тело покойного для осмотра в уездный город, и в документах встречаются упоминания о невозможности сделать это из-за бездорожья. В иных случаях, как правило, летом, если канцелярия медлила с присылкой чиновника, с мест сообщали, что не могут долго хранить тело покойного, и просили поскорее прислать кого-нибудь для его освидетельствования.

До проведения освидетельствования тела самоубийцы представителями власти на предмет обнаружения на нем “боевых знаков,” его не разрешалось хоронить. В абсолютном большинстве случаев так и происходило, но иногда тело самоубийцы было захоронено прежде освидетельствования, и в этом случае виновным приходилось как минимум оправдываться незнанием и “простотою.” Случаев наказания за подобное самоуправство не зафиксировано, однако иногда тело выкапывали, осматривали и убеждались в том, что действительно имело место самоубийство, причем иногда эксгумация проводилась через довольно продолжительное время, когда труп уже настолько разложился, что определить чтолибо было невозможно. Впрочем, и эксгумация проводилась не всегда. Так, к примеру, в 1772 г. в Ростовском уезде выборный помещичьего села кн. А. А. Засекина, докладывая о самоубийстве крестьянина Ивана Федорова, сообщал: “и после осмотру при вышеписанных же сторонних людех показанное мертвое тело во оной роще в глубокую яму зарыто и пеплом засыпано." канцелярии на это самоуправство не последовало. В Ряжском уезде в 1749 г. повесилась дворовая девка дьячка Василия Макарова, “и то мертвое тело от села Агламазова в сажень в десять в землю зарыто." ${ }^{8}$ Прибывший на место чиновник канцелярии опросил свидетелей, но эксгумации покойной не проводил.

Там, где это было возможно, освидетельствование тела самоубийцы осуществлялось профессиональными медиками. Стандартная формула в донесениях из Петербурга последней четверти века гласила: “А по осмотру штап-лекаря Нилуса 39

\footnotetext{
37 РГАДА, ф. 563, Ростовская воеводская канцелярия, оп. 1, д. 885, л. 7. (RGADA, f. 563, Rostovskaia voevodskaia kantseliariia, op. 1, d. 885, 1.7).

$3^{38}$ РГАДА, ф. 566, Ряжская воеводская канцелярия, оп. 1, д. 143, л. 1. (RGADA, f. 566, Riazhskaia voevodskaia kantseliariia, op. 1, d. 143, 1.1).

${ }^{39}$ Христиан Нилус - с 1773 г. штаб-лекарь, позднее - главный врач Санкт-Петербургской полиции.
} 
на оном теле боевых и опасных знаков не оказалось." ${ }^{40}$ На местах текст мог варьироваться: “На котором теле по осмотру нашему, кроме что от удавления на шее, никаких знаков не оказалось" ${ }^{\prime 1}$; или: “А по осмотру и описи явилось на шее от удавления веревкою красновато, а сверх того боевых ран и знаков ничего не имеетца." 42 В 1764 г. тело повесившегося в Петербурге и оставившего предсмертную записку офицера Василия Полетаева было решено “отослать в гофшпиталь к анатомии, для того по анатомии не признано ль будет в нем ипахондрии или других каких припадков, которыя б ево к тому удавлению привесть могли." 33 Надо заметить, что обязательное освидетельствование умерших насильственной смертью было введено все тем же Артикулом воинским (артикул 154), однако отсутствие на местах врачей и недостаток знаний в области судебной медицины (первый русский учебник по судебной медицине с отдельной главой о самоубийствах был издан только в 1832 г.), ${ }^{44}$ конечно же, не могли обеспечить квалифицированного проведения этой процедуры. ${ }^{45}$

После освидетельствования и установления факта самоубийства вставал вопрос о форме захоронения покойника. Как уже упоминалось, в странах Европы раннего Нового времени это была прерогатива светских или церковных властей. В Саксонии начала XVIII в. по этому поводу разгорелся конфликт между городским советом Лейпцига и церковью, в основе которого, по мнению К. Козлофски, было соображение о том, что “тело самоубийцы оставалось важным, хотя и противоречивым символом как для местных жителей, так и для образованных чиновников." 46 В России, где в ходе петровских реформ церковь стала фактически частью государственного аппарата, подобный конфликт, по крайней мере, в открытой форме, был в принципе невозможен и сомнения в приоритете светской власти, как кажется, не возникали. Само по себе это можно рассматривать как секуляризацию самоубийства, но при этом отсутствие в законе соответствующих четких норм порождало разнообразие принимавшихся решений. В целом можно выделить два основных способа организации захоронения: тело покойного либо отдавалось родственникам без каких-либо конкретных предписаний, и им, повидимому, далее предстояло договариваться о похоронах с местным священником, либо власти осуществляли захоронение сами. В некоторых регионах канцелярии по собственной инициативе обращались в местные духовные консистории, предлагая им определить место захоронения, или просто отсылали тело к местному священнику, чтобы он отдал соответствующие распоряжения. Можно предположить,

\footnotetext{
${ }^{40}$ РГАДА, ф. 16, Внутреннее управление, д. 481, ч. 4, л. 420б. (RGADA, f. 16, Vnutrennee upravlenie, d. 481, ch. 4, 1. 420b.).

${ }^{41}$ РГАДА, ф. 425, Вятская провинциальная канцелярия, оп. 5, д. 413, л. 1. (RGADA, f. 425, Viatskaia provintsial'naia kantseliariia, op.5, d. 413, 1. 1).

${ }_{42}$ РГАДА, ф. 442, Путивльская провинциальная канцелярия, оп.1, д. 286, л. 1 (RGADA, f. 442, Putivl'skaia provintsial'naia kantseliariia, op. 1, d. 286, 1.1).

${ }_{43}$ РГАДА, ф. 16, д. 473, л. 210. (RGADA, f. 16, d. 473, 1. 210).

${ }^{44}$ С. А. Громов, Краткое изложение судебной медицины (Санкт-Петербург: Типография Штаба Отдельнаго Корпуса Внутренней Стражи, 1832). (S. A. Gromov, Kratkoe izlozhenie sudebnoi meditisiny (St. Petersburg: Tipografiia Shtaba Otdel'nago Korpusa Vnutrennei Strazhi, 1832)).

45 Порядок осмотра мертвых тел был определен лишь в 1797 г. высочайше утвержденным докладом Медицинской коллегии. См. Полное собрание законов Российской империи, т. 24 (Санкт-Петербург: Типография II Отделения Собственной Его Императорскаго Величества Канцелярии, 1830), №17743, 287-296. (Polnoe sobranie zakonov Rossiiskoi imperii, t. 24 (St. Petersburg: Tipografiia II Otdeleniia Sobstvenoi Ego Imperatorskago Velichestva Kantseliarii, 1830), no. 17743, 287-296).

${ }^{46}$ Craig M. Koslofsky, "Controlling the Body of the Suicide in Saxony," From Sin to Insanity, 53.
} 
что там, где подобные практики имели место, это было связано либо со сложившимися еще в допетровское время традициями, либо с тем, что местные церковные власти были особенно авторитетны, однако установить это по имеющимся в нашем распоряжении источникам не представляется возможным. Стоит при этом заметить, что никаких следов привлечения церкви к решению вопроса о форме захоронения петербургских самоубийц не обнаружено, и в рапортах императрице ограничивались коротким сообщением “и то тело в надлежащем месте зарыто.” По-видимому, зная, что самоубийцу надо хоронить не по церковному обряду, власти попросту не считали нужным привлекать к этой процедуре духовенство, что подтверждает тезис о секуляризации этого феномена.

Хоронили самоубийц, как правило, в отдаленном от поселения месте, в лесу, в поле, но иногда и у церковной ограды. В документах тех учреждений, которые сами распоряжались о порядке похорон, находим разного рода формулировки, различающиеся в зависимости от географии - похоронить “в удобном месте" (Дмитровский уезд, 1779 г.) ${ }^{47}$ или, наоборот, “тело погресть в неудобном месте” (Кинешемский уезд, 1775 г.). ${ }^{48}$ Однако три года спустя в том же уезде выражаются совсем по-другому: “тело велеть похранить при церкви села Жирятина без церковнаго по должности христианской.” 49 В Обоянском уезде в 1757 г. пишут: “ежели по осмотру явится, что не от удавления и не от пьянства, то по закону христианскому похоронить ево при церкви, а ежели от удавления или от пьянства умер, то похоронить от жилья в пустом месте,"50 в Ростовской провинции в 1770 г. - “для зарытья в поле," ${ }^{11}$ в Великоустюжской провинции в 1764 г. - “закопать в отдаленности х крайнему бесчестию без всякой по церковному преданию церемонии." ${ }^{2}$ В Вятской провинции в 1772 г. тело повесившегося сборщика подушной подати Михаила Тюкалова было велено “караульному сержанту 3 дневальным канцеляристом, осмотря, описать и, ежель на оном теле никаких боевых признаков не окажется, то оной осмотр приобщить к делу, а мертвое тело чрез палача зарыть в отдаленном от жительства месте в землю.”53 Заметим, что эти формулировки свидетельствуют о том, что чиновники сами принимали решение о форме погребения и, по крайней мере, в последнем случае представители церкви к погребению не привлекались вовсе. В Петербурге случалось и иное. Так, в 1772 г. тело покончившей с собой жены адмиралтейского плотника было отослано “для практического в анатомии упражнения в учрежденную при Академии наук комисию.” 54 Лишь единожды в изученных документах (дело о самоубийстве в 1754 г. в Кашинском уезде

\footnotetext{
${ }^{47}$ РГАДА, ф. 482, Дмитровская воеводская канцелярия, оп. 1, д. 12729, л. 5. (RGADA, f. 482, Dmitrovskaia voevodskaia kantseliariia, op. 1, d. 12729, 1.5).

${ }^{48}$ РГАДА, ф. 504, Кинешемская воеводская канцелярия, оп. 1, д. 1998, л. 12. (RGADA, f.504, Kineshemskaia voevodskaia kantseliariia, op. 1, d. 1998, 1. 12).

49 Там же, оп. 1, д. 2311, л. 2об. (Таm zhe, op. 1, d. 2311, 1. 2ob.).

50 РГАДА, ф. 545, Обоянская воеводская канцелярия, д. 2275, л.2. (RGADA, f. 545, Oboianskaia voevodskaia kantseliariia, op. 1, d. 2275, 1. 2).

${ }^{51}$ РГАДА, ф. 563, Ростовская воеводская канцелярия, оп. 1, д. 819, л. 3. (RGADA, f. 563, Rostovskaia voevodskaia kantseliariia, op. 1, d. 819, 1. 3).

$5^{2}$ РГАДА, ф. 451, Великоустюжская провинциальная канцелярия. оп, 1, д. 932, л. 3. (RGADA, f. 451, Velikoustiuzhskaia provintsial'naia kantseliariia, op. 1, d. 932, 1. 3).

53 РГАДА, ф. 425, Вятская провинциальная канцелярия, оп. 5, д.413, л. 2. (RGADA, f. 425, Viatskaia provintsial'naia kantseliariia, op. 5, d. 413, 1. 2).

${ }^{54}$ РГАДА, ф. 16, д. 481, ч. 4, л. 112. (RGADA, f. 16, d. 481, ch. 4, 1. 112).
} 
монастырского сторожа Трофима Федотова) $)^{55}$ упоминается убогий дом, куда было отправлено тело самоубийцы. По-видимому, это свидетельствует о том, что распространенная в предшествующие века практика помещения тел самоубийц в ямы (скудельницы) и закапывания их в четверг седьмой недели после Пасхи, в основном исчезла задолго до того, как убогие дома были запрещены Екатериной II в 1771 г. ${ }^{56}$

Сведения о форме захоронения имеются далеко не во всех делах о самоубийствах, но также нет в них и никаких следов попыток близких покойного воздействовать на решения властей. Означает ли это, что русские люди были равнодушны к посмертной судьбе своих близких и что факт захоронения тела самоубийцы вне кладбища не воспринимался как бесчестье, позор для семьи и всей общины? Или, может быть, сам порядок принятия соответствующего решения не предусматривал возможности на него повлиять и тем более оспорить?

Между тем, в источниках, хоть и редко, но встречаются случаи, когда с позволения местного священника тело самоубийцы было захоронено без надлежащего осмотра. Так, в 1767 г. в Кологривском уезде была похоронена повесившаяся крестьянка Дарья Сергеева. Ее муж Карп на следствии показал, что он и его зять Иван, “сходя приходу своего к попу Дмитрею Иванову церкви Воскресения Христова, что в Березниках, и о том объявили ему, попу, и просил ево, попа, оной зять ево, чтоб дозволил ее хоронить у церкви, которой и приказал. И того ж 24 числа июля днем тое тело жены своей он, Карп, обще с показанным зятем своим Иваном у церкви Божии, выкопав могилу, с позволения означенного попа и похоронили без службы, при коих похоронах был и оной поп, а о том, чтоб ее осмотреть тоя вотчины старосте и выборному он... не объявил, потому что их в то время в доме их не было, а были на сенокосе. Також и сотцкому сотни своей не объявили ж просто[то]ю своею." ${ }^{77}$ В воеводской канцелярии было решено тело выкопать и осмотреть, однако ничего криминального обнаружено не было, и крестьян, похоронивших женщину “простотою,” отпустили, а о давшем им разрешение на похороны священнике, как о нарушителе закона, сообщили в духовную консисторию. Трудно сказать, насколько искренни были Карп и Иван, отговариваясь своей “простотою,” но очевидно, что им было небезразлично, где похоронить покойную, и, вполне вероятно, они заплатили за разрешение священнику, который, по-видимому, либо полагал, что дать подобное разрешение в его власти, либо надеялся, что это удастся скрыть.

Как и в других европейских странах, и как оговаривалось в Артикуле воинском, установленный факт безумия или иной болезни самоубийцы мог стать основанием для погребения по церковному обряду. Так, повесившийся в 1761 г. в Клинском уезде бобыль Иван Федоров, который был “года с три в безумстве," “того погоста священником Иваном Алексеевым в том погосте при церкви божией с нагробным отпеванием погребен., ${ }^{8}$ При церкви и с участием священника была похоронена и утопившаяся в колодце в 1754 г. в Коломенском уезде крестьянка Елена Клеменова,

55 РГАДА, ф. 501, Кашинская воеводская канцелярия, оп. 1., д. 847, л. 7. (RGADA, f. 501, Kashinskaia voevodskaia kantseliariia, op. 1, d. 847, 1. 7).

${ }^{56}$ См. И. М. Снегирев, “О скудельницах или убогих домах в России,” Труды и записки Императорского Общества истории древностей Российских, т.3, кн. 1. (1826): 235-263. (I. M. Snegirev, "O skudel'nitsakh ili ubogikh domakh v Rossii," Trudy i zapiski Imperatorskogo Obshchestva istorii drevnostei Rossiiskikh, t. 3, kn. 1 (1826): 235-263).

${ }^{57}$ РГАДА, ф. 508, Кологривская воеводская канцелярия, оп. 1, д. 166, л. 1-6. (RGADA, f. 508, Kologrivskaia voevodskaia kantseliariia, op. 1, d. 166, 1. 1-6).

${ }^{8}$ РГАДА, ф. 505, Клинская воеводская канцелярия, оп. 1, д. 2505, л. 4. (RGADA, f. 505, Klinskaia voevodskaia kantseliariia, op. 1, d. 2505, 1. 4). 
которая “находилась в полоумстве, а времянно и без ума.”59 Вероятно, церковного погребения удостоилась и зарезавшаяся, “будучи малоумная,” в 1778 г. в Дмитровском уезде и успевшая перед смертью исповедоваться крестьянская вдова Ефросинья Евдокимова. ${ }^{60}$ "При церкви божией с нагробным отпеванием погребен” был повесившийся в 1761 г. в Клинском уезде бобыль Иван Федоров, который был “года с три в безумстве." ${ }^{1}$ Однако последовательного исполнения этой нормы всеми судебно-административными учреждениями проследить по архивным документам невозможно.

Норма Артикула воинского о наказании тела самоубийцы, требовавшая волочить его по улице, судя по упоминаниям в документах, исполнялась редко и далеко не везде. Так, в том же Кинешемском уезде подканцелярист Макар Потехин в 1774 г. рапортовал: “на шее сине и багрово от бывшей на шее опоески, почему велел я того села пятидесяцким и десяцким протащить за ноги чрез то село по улицам и по протащении отвезен в лес в отдаленное от жилья и от дорог место и зарыт в глубочайшую яму." ${ }^{2}$ Великоустюжская провинциальная канцелярия в 1759 г. распорядилась: “а оное мертвое тело, волоча по улицам, зарыть в бесчестное место в яму." 33 Пять лет спустя эта же канцелярия велела: “в силу точного на то военного артикула повеления, волоча довольно улицам, дабы, смотря на то, другие от таковаго противнаго законом предприятия удерживались." ${ }^{64}$ При этом в первом случае речь шла об удавившемся работавшем на мельнице взрослом мужчине, а во втором - о молодой девушке, повесившейся, судя по всему, из-за обиды на отругавшую ее мать.

Редкость использования этой нормы Артикула, как можно предположить, связана с тем, что смысл заимствованной в западноевропейском праве процедуры протаскивания тела самоубийцы по улицам многим местным чиновниками был непонятен и она воспринималась как чуждая, излишняя, да к тому же требовавшая дополнительных усилий.

Что же касается причины самоубийства, когда сам его факт уже не вызывал сомнений, то она интересовала власти в гораздо меньшей степени. В использованных Моррисей донесениях Петербургского губернатора Екатерине II в качестве причин чаще всего называются пьянство, болезнь, “тоска," “задумчивость," “меланхолия,” страх перед наказанием, с которыми было принято связывать самоубийство в эту эпоху и в других странах. Примечательна резолюция Устюжны-Железопольской воеводской канцелярии 1766 г.:

Понеже вышеписанной крестьянин Иван Савельев, на дереве висящей, найден мертвой, а действительно познать не можно, сам ли собою он удавился, или от кого умерщвлен, и по двоекратным посылкам чрез копеистов Бубнова и Посникова того не сыскано, также и чтоб ис посторонних кто такое над ним удавление учинил, в том никакого подозрения и приличества не оказалось, потому что при нем денег и протчих побуждающих к зависти вещей не было, по которым

\footnotetext{
59 РГАДА, ф. 509, Коломенская воеводская канцелярия, оп. 3, д. 209, л. 1-2. (RGADA, f. 509, Kolomenskaia voevodskaia kantseliariia, op. 3, d. 209, 1. 1-2).

${ }^{60}$ РГАДА, ф. 482, оп. 1, д. 12279, л. 1-3. (RGADA, f. 482, ор.1, d. 12279, 1. 1-3).

${ }^{61}$ РГАДА, ф. 505, оп. 1, д. 2505, л. 4. (RGADA, f. 505, ор. 1, d. 2505, 1. 4).

${ }^{62}$ РГАДА, ф. 504, оп. 1, д. 1933, л. 4. (RGADA, f. 504, ор. 1, d. 1933, 1. 4).

${ }^{63}$ РГАДА, ф. 451, оп. 1, д. 791, л. 7. (RGADA, f. 451, op. 1, d. 791, 1. 7).

${ }^{64}$ Там же, д. 932, л. 3. (Tam zhe, d. 932, 1. 3).
} 
обстоятельствам больше сходствует с тем, что он от каких-либо неизвестных притчин, от меланхолии или тоски, или и в пьянстве будучи, что нередко между подлыми людьми бывает, сам удавился."

Вместе с тем, если петербургские губернаторы довольно уверенно называли причины самоубийств, в документах провинциальных учреждений они зачастую не упоминаются вовсе, хотя иногда на них указывают косвенные данные, как, например, описание сопутствовавших случившемуся обстоятельств. Подававшиеся в провинциальные, воеводские канцелярии и городовые магистраты первоначальные рапорты сотских, десятских и сельских старост, как правило, содержали формулу “неведомо каким случаем."

Если, к примеру, в Швеции, после осмотра тела, проводившегося с теми же целями, что и в России, факт самоубийства и его обстоятельства устанавливались в судебном заседании на основе показаний свидетелей, в России власти проводили опрос свидетелей или соседей далеко не всегда и опять же не столько с целью выяснения причины случившегося, столько с тем, чтобы установить, что имело место именно самоубийство. При этом, поскольку, такого понятия, как доведение до самоубийства и, соответственно, наказания за это законодательство того времени не знало, ${ }^{66}$ то даже в тех редких случаях, когда подобные подозрения могли возникнуть, а это касается в первую очередь женских самоубийств, ибо зафиксировано несколько случаев, когда кончали с собой молодые женщины, только что вышедшие замуж, или, когда мужья признавались в том, что избивали своих жен, ни в одном из изученных кейсов обвинение никому предъявлено не было. Едва ли не единственным исключением является случай, зафиксированный в документах Добренской воеводской канцелярии за 1778 г. Пойманный на воровстве однодворец Евдоким Голев был избит сельскими выборным и десятским, после чего зарезался, успев указать исповедовавшему его священнику на своих обидчиков. По окончании длившегося в течение года разбирательства канцелярия постановила выборного и десятского наказать батогами, но не за то, что они довели человека до самоубийства, а за то превысили свои полномочия. ${ }^{67}$ Еще один, по-своему уникальный случай зафиксирован в Кинешемском уезде. Приведенная выше цитата “тело погресть в неудобном месте” относится к делу о самоубийстве в 1775 г. помещичьей крестьянки Афросиньи Ивановой. Показания свидетелей разнились как относительно способа самоубийства - то ли она зарезалась, то ли повесилась (у нее было порезано горло, но рядом с телом валялась веревка), так и о состоянии ее душевного здоровья. Сельский староста утверждал, что “она, Афросинья, обдержима была в болезни лихорадкою," а ее свекор напротив, что “напред сего в безумии и меленколиях она, Афросинья, не бывала.” Видимо, поэтому воеводская канцелярия решила направить

\footnotetext{
${ }^{65}$ РГАДА, ф. 596, Устюжна-Железопольская воеводская канцелярия, оп. 1, д. 379, л. 30. (RGADA, f. 596, Ustiuzhna-Zhelezopol'skaia voevodskaia kantseliariia, op. 1, d. 379, 1. 30).

${ }^{66}$ Норма закона о доведении до самоубийства появляется лишь в "Уложении о наказаниях уголовных и исправительных" 1845 г. СМ. Е. В. Буряковская "Уголовно-правовая и криминологическая характеристика доведения до самоубийства," (Диссертация на соискание ученой степени кандидата юридических наук, Санкт-Петербургский государственный университет, 2019), 25. (Е. V. Buriakovskaia, "Ugolovno-pravovaia i kriminologicheskaia kharakteristika dovedeniia do samoubiistva," (Dissertatsiia na soiskanie uchenoi stepeni kandidata iuridicheskikh nauk, Sankt-Peterburgskii gosudarstvennyi universitet, 2019), 25).

${ }^{67}$ РГАДА, ф. 483, Добренская воеводская канцелярия, оп. 1, д. 483, л. 1-106. (RGADA, f. 483, Dobrenskaia voevodskaia kantseliariia, op. 1, d. 483, 1. 1- 106).
} 
на похороны своего служащего, дабы “при том разведать, не окажется ль при погребении того тела от кого взарезана каковаго-либо разглашения." ${ }^{8}$

В абсолютном же большинстве случаев свидетели либо подтверждали сведения родственников о болезни покойного, либо, когда речь шла о женском самоубийстве, уверяли представителей власти в том, что ни о каких ссорах в семье покойной никогда не слышали и она ни на что не жаловалась, ${ }^{69}$ либо вовсе отговаривались незнанием. Подобное единодушие можно, видимо, объяснить как соседской солидарностью, так и нежеланием лишний раз иметь дело с официальной властью, то есть с государством. ${ }^{70}$

Из архивных документов хорошо видно, что разные учреждения относились к расследованию случаев самоубийства с разной степенью тщательности. Примером серьезного отношения к делу может служить Великоустюжская провинциальная канцелярия (не случайно она столь ревностно следовала букве закона в части наказания тела самоубийцы). Так, в 1761 г., расследуя самоубийство крестьянки Ефросиньи Чюриной, чиновники канцелярии тщательно зафиксировали изобилующие характерной для этой местности лексикой и бытовыми деталями подробные показания членов ее семьи и соседей. Согласно доношению сотского Федота Уланова, первым осмотревшего тело Ефросиньи:

Оная женка оказалась мертва против клетных дверей на полу, токмо над ней шест, а выше шеста имеется кровельная слега, за которую слегу той веревкой захвачено и утвержено накрепко и сочинена петля, а по осмотру та петля перерезана и оной обрезок той петли и лежит при той женке на полу, а по сторон той петли на том полу стоит о дву ногах пенковая мялица, ${ }^{71}$ а у той женки на шее кругом значит красной рубец, а больше того на ней никаких ран не оказалось.

Деверь (брат мужа) покойной Лука Чюрин показал:

Я пришел после службы от часов, токмо я в доме своем никого не застал, и пришла ко мне в дом мати моя Анна и спрошала у меня, где сноха, и я ей сказал, что я ее в доме не застал, токмо она меня и стала посылать искать, чтоб идти в онбар порож, и я вышел из избы на мост искать помянутой оной снохи, токмо я и увидал в дальном конце за поветью ${ }^{72}$

\footnotetext{
${ }^{68}$ РГАДА, ф. 504, оп. 1, д. 1998, л. 1-12. (RGADA, f. 504, ор. 1, d. 1998, 1. 1-12).

${ }^{69}$ Выяснение подобных причин самоубийства можно трактовать и как установление факта доведения до самоубийства, но в случае, если бы это было установлено, виновный, в силу отсутствия в законодательстве соответствующей статьи, мог быть наказан лишь за чрезмерное применение силы. $7^{70} \mathrm{O}$ нежелании населения сотрудничать со следствием, чтобы не “свидетельствовать против соседа" и не “выдать своих" во время повальных обысков см. Н. Ш. Коллманн, Преступление и наказание в России раннего Нового времени (Москва: Новое литературное обозрение, 2016), 176-177. (N. S. Kollmann, Prestuplenie i nakazanie v Rossii rannego Novogo vremeni (Moscow: Novoe literaturnoe obozrenie, 2016), 176177.

${ }^{71}$ Мялица - инструмент, которым мнут лён и коноплю, очищая волокна от кострицы.

$7^{2}$ Согласно В. И. Далю, поветь - это “крытое место, простор с верхом; крыша, кровля, обвершка нежилого строенья; верх, чердак, подволока на холодном, надворном строении; хлев, сарай... сенник, сеновал; крыша над скотным двором, частью застилаемая накатом... крыша над всем двором, или над воротами и переднею половиной двора, до дрина; крытый, теплый двор.” См. В. И. Даль, Толковый словарь живаго великорусскаго языка, т. 3 (Москва: Типография лазаревскаго института восточныхъ
} 
против клетных дверей стоит, и я стал кликать, токмо она мне никакого ответу не дает, и я к ней по повете и пошел и, не дошед к ней, и мне то чаетельно, что она на голове починивает, и я против лошадей своих стал давать овсяную солому в небытность сена, токмо за мной на ту поветь и пришла мать моя Анна к той моей снохе и увидела, что она в веревке мертва, и стала меня мати посылать по суседку свою Марину Логинову дочь, и я по нее и сходил к ней, и пришла, а как она шла, и я ее обежал и пришед к матере своей, и она меня послала в избу по ножик, и оной нож и принес, и она мне ту веревку и велела отрезать, то я и отрезал.

Показания сына дополнила свекровь Ефросиньи Анна Чюрина:

Из дому своего уходила к суседу своему Алексею Кашникову по мешек житной и с тем мешком и пришла в дом свой и ее не застала, а как я по тот мешек пошла, то оная сноха и осталась от меня в избе под красным окном за прельцем, а застала сына своего Луку, и я у него про ту сноху спросила, и он мне сказал, что де я пришел от часов, а той снохи в доме не застал, и я ево и стала посылать искать, чтоб с ней сходить в житной анбар по рожь, и я из ызбы на повет и пошла овцам по корм. Токмо на той повете оной сын мой Лука дает корм лошадем, и он мне сказал, что де сноха стоит у клети, и я к ней згаркала, ${ }^{73}$ и она мне и голосу не подала, и я к ней и пришла и умотрила, что виситца в веревке, то и послала ево Луку по суседей, токмо и пришла суседка Марина Логинова дочь, а тои снохе моей сродная сестра, при которой сын мой Лука оную веревку и перерезал, и мы ее на полу и стали откачивать чаетельно от нее жизни, а в то время пришел и сусед мой Гаврило Чюрин.

Сестра Ефросиньи Марина подтвердила:

Ко мне пришел Лука и сказал, что де ты бежи скоряя, сноха наша удавилась в веревке, и я к ней и пришла, и она виситца в веревке мертва, токмо я по той сестре сплакала и свету не увидала, и стала быть нечуственна, и больше того ничего не знаю, а прежных от той сестры как в побоях, так и в бранных словах никаких жалоб не слыхала.

Муж покойной Кузьма “в доме своем не был, а был в отлучке в деревне Ламенской у зятя своево Кондратья Малафиевских для занятия денег в подушной збор;” сосед Гаврило Чюрин "ехал по улице з дровами и услышил, что плачут, и я тут пришел, и оная женка на полу мертва, а прежных жалоб от той женки никаких не слыхал." Ничего не слыхали и другие опрошенные соседи. ${ }^{74}$

языковъ, 1865), 1зо. (V. I. Dal', Tolkovyi slovar' zhivago velikorusskago iazyka, t. 3 (Moscow: Tipografiia lazarevskago instituta vostochnykh iazykov, 1865), 130).

${ }^{73}$ Согласно В. И. Далю, гаркать - “громко кричать, зычно орать, зевать; звать, кликать.” См. В. И. Даль, Толковый словарь живаго великорусскаго языка, т. 1 (Москва: Типография лазаревскаго института восточныхъ языковъ, 1863), 304. (V. I. Dal', Tolkovyi slovar' zhivago velikorusskago iazyka, t. 1 (Moscow: Tipografiia lazarevskago instituta vostochnykh iazykov, 1863), 304).

74 РГАДА, ф. 451, оп. 1, д. 857, л. 1-4. (RGADA, f. 451, ор. 1, d. 857, 1. 1-4). 
Пример сугубо бюрократического усердия проявили чиновники г. Севска. В 1762 г. Севская провинциальная канцелярия, расследовала самоубийство крестьянки Анны Трофимовой дочери. О случившемся властям объявил ее свекор Самойла Антонов, утверждавший, что “он, Самойла, не токмо, чтоб когда бить, но и угорозов как пред тем, так и никогда не чинил.” На теле покойной “явилось на шее от удавления веревкою красновато, а сверх того боевых ран и знаков ничего не имеетца." Приведенные в Севск сельский староста и крестьяне-свидетели подтвердили показания Самойлы, но в канцелярии по какой-то причине не поверили, что в семье не было ссор (муж Анны, непонятно почему, в деле не фигурирует) и постановили провести повальный обыск. Однако решение это так и не было претворено в жизнь, на что в 1787 г. (25 лет спустя!) обратили внимание в Севской нижней расправе и, дабы закрыть дело, решили довести его до конца. Допросить Самойлу было уже невозможно, поскольку он находился “в жестокой болезни.” Повальный обыск спустя четверть века, конечно, тоже ничего не дал, но зато теперь все формальности были выполнены, и дело можно было закрыть. ${ }^{75}$

Очевидно, что степень усердия властей в выяснении причины самоубийства зависела также от социального положения жертвы и, когда речь шла о дворянине, они проявляли гораздо больше рвения, чем, когда самоубийцей был простой крестьянин или дворовый. Показательно в этом отношении дело о самоубийстве отставного генерал-майора, в прошлом командира Семеновского полка Степана Андреевича Шепелева, застрелившегося в своем московском доме 25 ноября 1750 г. в день, когда вся Россия праздновала очередную годовщину восшествия на престол императрицы Елизаветы Петровны. Очевидно, что самоубийство генерала было чрезвычайным происшествием, но появление на свет десятков листов следственного дела в фонде Сыскного приказа и еще более пухлого дела в фонде Сената, ${ }^{76}$ включающего переписку главнокомандующего Москвы В. Я. Левашова с главой Кабинета императрицы бароном И. А. Черкасовым, объясняется, по-видимому, еще и тем, что покойный был не только обладателем довольно высокого чина, но и братом генерал-аншефа, обер-гофмаршала двора Дмитрия Андреевича Шепелева, руководившего строительством Зимнего дворца. Причем жена Дмитрия Андреевича была родственницей пастора Глюка, имевшего непосредственное отношение к биографии императрицы Екатерины I, а оба Шепелевы были дальними родственниками подруги Елизаветы Петровны Мавры Егоровны, жены П. И. Шувалова. ${ }^{7}$

В момент совершения самоубийства Степан Андреевич был под следствием по доношению на него обер-полицмейстера А. Д. Татищева с обвинениями в “буйных поступках" и находился под домашним арестом. Расследование его самоубийства было весьма тщательным. Не только были допрошены все дворовые, находившиеся в момент самоубийства в доме генерала, но целая делегация чиновников Сыскного приказа специально выезжала для осмотра места происшествия, а из Петербурга затребовали план дома Шепелева, который по приказу Левашова был выполнен лично архитектором Д. В. Ухтомским и также сохранился в материалах Сената. ${ }^{78}$ Медицинское освидетельствование, проведенное будущим директором

\footnotetext{
75 РГАДА, ф. 442, оп. 1, д. 286, л. 1-51. (RGADA, f. 442, op.1, d. 286, 1. 1-51).

${ }^{76}$ РГАДА, ф. 372, Сыскной приказ, д. 2415; ф. 248, Сенат, кн. 7927, л. 262-343. (RGADA, f. 372, Sysknoi prikaz, d. 2415; f. 28, Senat, kn. 7927, l. 262-343). За указание на это дело благодарю Е. Е. Рычаловского.

77 Одной из жен Степана Андреевича была дочь В. Н. Татищева.

${ }^{78}$ РГАДА, ф. 248, оп. 160, д. 1818. (RGADA, f. 248, оp. 160, d. 1818).
} 
Медицинской канцелярии Иоганном Лерхе и главным лекарем Вильгельмом Риттером, установило: “на теле оного Шепелева на правом виске прострелена рана, и около тое раны волосы и кожа опалены, по чему видно, что пистолет к самому виску был приложен, и оная рана насквозь вышла на другую сторону пониже темя."

В результате следствия подозрения с дворовых были сняты, факт самоубийства установлен и тело покойного было отдано его сыну, будущему генерал-поручику Амплию Степановичу Шепелеву, ${ }^{79}$ который отвез его для погребения в имение своего дяди Д. А. Шепелева в с. Валуево Московского уезда, ${ }^{80}$ где и похоронил "при церкви." ${ }^{81}$ Понятно, что при этом не только не было речи о том, чтобы протаскивать тело генерала, к которому нормы Артикула воинского имели прямое отношение, по московским улицам, но и детали захоронения никак не были обозначены. ${ }^{82}$

Из дела следует, что буквально накануне самоубийства Шепелев был оправдан и должен был быть освобожден: следственная комиссия по его делу, состоявшая из статского советника А. И. Львова, ${ }^{83}$ советника Мануфактур-коллегии кн. И. М. Одоевского $^{84}$ и советника Сибирского приказа М. В. Сушкова, очевидно, ему благоволила. Но то ли бравый генерал не успел узнать об их решении, ${ }^{85}$ то ли ему уже было все равно, и он свел счеты с жизнью выстрелом в висок. В литературе самоубийство Шепелева обычно объясняется тем, что он хотел избежать позора. Это выглядит достаточно правдоподобно, но, как представляется, возможна и другая версия. В отличие от утопившегося в 1731 г. В. И. Апухтина, чье поведение носило гораздо более экстравагантный характер и который боялся, что его станут пытать, ${ }^{86}$ Шепелеву за его “буйства” вряд ли угрожало какое-либо позорное наказание, кроме денежных штрафов, которые к тому же уже были в основном уплачены. Даже

\footnotetext{
${ }^{79}$ Сын Степана Андреевича Амплий Шепелев был женат на дочери гр. А. А. Матвеева, а его сын Петр, также генерал-поручик и сенатор, приходился, таким образом, двоюродным братом фельдмаршалу П. А. Румянцеву-Задунайскому. Примечательно, что в 1735 г. в Синоде рассматривалось дело по обвинению жены знаменитого шута Петра I Ивана Балакирева в прелюбодейной связи с камер-пажом Амплием Шепелевым. См. Описание документов и дел, хранящихся в архиве Святейшего Правительствующего Синода, т. 15 (Санкт-Петербург: Синодальная типография, 1907), 264-267. (Opisanie dokumentov i del, khraniashchikhsia v arkhive Sviateishego Pravitel'shvuiushchego Synoda, t. 15 (St. Petersburg: Sinoldal'naia tipografiia, 1907). 264-267).

80 Ныне поселок в Новомосковском административном округе Москвы, где сохранилась усадьба следующего владельца - А. И. Мусина-Пушкина, в которой в настоящее время располагается санаторий. Имение было продано Д. А. Шепелеву в 1742 г. потомками П. А. Толстого, и он построил там усадебную церковь Покрова Богородицы, которая была снесена в 1930-е гг.

${ }^{81}$ РГАДА, ф. 248, кн. 7927, л. 3250б. (RGADA, f. 248, kn. 7927, l. 325ob.).

${ }^{82}$ Игнорирование закона в случае самоубийства человека из высших слоев общества не было, конечно, чисто русским явлением. Так, в Англии не предстали перед судом в качестве обвиняемых покончивший с собой в 1770 г. канцлер Чарлз Йорк, а в 1774 г. первый губернатор Бенгалии Роберт Клайв, что стало предметом критики в публицистике того времени. При этом, на протяжении всего столетия усиливалась тенденция признания судами причиной самоубийства почти исключительно сумасшествия, что делало невозможным применение к ним нормы закона о конфискации имущества в пользу короны и вызывало протест современников, подозревавших судей во взяточничестве. У. Блэкстоун считал эту тенденцию весьма опасной, поскольку таким образом можно трактовать любое преступление. См. Andrew, Aristocratic Vice, 93-104.

$8_{3}$ Позднее тайный советник и в 1753-1758 гг. обер-прокурор Синода.

${ }^{84}$ Позднее президент Вотчинной коллегии.

${ }^{85}$ Комиссия приняла решение по делу Шепелева 8 ноября 1750 г. и в тот же день соответствующий экстракт решения был послан в Петербург для доклада императрице, но ответ, по-видимому, не был получен до самоубийства 25 ноября.

${ }^{86}$ См. А. Б. Каменский, “Государственный Страх, или Случай Майора Апухтина,” Quaestio Rossica, 7:2 (2019): 630-647. (A. B. Kamenskii, "Gosudarstvennyi strakh, ili sluchai Maiora Apukhtina," Quaestio Rossica, 7:2 (2019): 630-647).
} 
предъявленные ему обвинения в неуважении к полицейским чинам были фактически отметены, поскольку члены комиссии умудрились найти нарушения в действиях самих полицейских. Скорее всего, Шепелева угнетал сам факт следствия и домашнего ареста, необходимость давать показания и оправдываться. Непосредственно перед тем, как застрелиться, Шепелев принимал у себя знакомого священника, и тот не заметил в его поведении ничего необычного, но В. Я. Левашов писал Д. А. Шепелеву, что “как уже известно было, предписанной господин генералмаеор Шепелев уже во опохондрии был."

Понятно, что страх перед наказанием, болезнь или сумасшествие, как и меланхолия или ипохондрия, то есть то, что в наши дни называется депрессией, были не единственными причинами самоубийств русских людей XVIII в. Однако, если в Швеции второй половины XVII - начала XVIII в. свидетели помимо этого в качестве причин самоубийств называли бедственное экономическое положение и даже нищету покойника, или переживания по поводу смерти членов семьи, в особенности жены или мужа, ${ }^{88}$ то в российских документах подобных упоминаний не встречается. ${ }^{89}$ Это обстоятельство дает повод порассуждать о том, что не имевшему собственности русскому крестьянину или дворовому человеку разорение не грозило, а нищета была его обычным состоянием, ${ }^{90}$ в то время как проявления супружеской любви как минимум никак не манифестировались и, вероятно, этические нормы и нормы поведения этого времени (по крайней мере, в крестьянской среде) еще не предусматривали откровенного проявления тоски по умершему супругу или супруге. Однако, во-первых, в отличие от практики, принятой в Швеции, в значительной части изученных архивных дел какие-либо указания на причины или повод к самоубийству отсутствуют вовсе. Во-вторых, отсутствие подобных упоминаний вовсе не означает, что русские люди XVIII века не испытывали подобных чувств. ${ }^{91}$

Как следует из приведенных выше примеров, в случае самоубийства женщин власти обычно выясняли, не было ли в семье ссор и проявлений насилия по отношению к покойной, однако, как уже упоминалось, случаев предъявления комулибо обвинений в доведении до самоубийства не зафиксировано. В этой связи может возникнуть вопрос: а зачем вообще в таком случае власти выясняли причину самоубийства? Во-первых, потому что от этого зависела форма погребения. Во-

\footnotetext{
${ }^{87}$ РГАДА, ф. 248, кн. 7927, л. 307. (RGADA, f. 248, kn. 7927, 1. 307).

${ }^{88}$ Miettinen, Suicide, Law, and Community, 259.

89 Единственное упоминание подобного рода относится к самоубийству в 1792 г. отставного подпоручика Василия Бельяминова, о котором его родственница сообщила, что “как ей известно, что многим задолжал, то и полагает, что он застрелился” (РГАДА, ф. 16, д. 526, ч. 7, л. 12.). (RGADA, f. 16, d. 526 , ch. 7, l. 12).

${ }_{90}$ Само представление о бедности и нищете у русского и шведского крестьянина было, конечно же, различным.

91 Примечательно, к примеру, что убийца Алексей Жуков, которого современная исследовательница называет “духовно больным человеком,” спустя многие годы, проведенные в монастыре, жалуясь на свое бедственное положение, просил императрицу “о встрече с Варварой, вечной ссылке на поселение с женой или хотя бы о постриге его в монастырь Тобольской епархии, ближе к той, с которой 20 лет назад он убил свою мать." Не получив ответа, два года спустя "он повесился в собственной камере" на Соловках. См. Е. Н. Марасинова, "Закон” и “гражданин” в России второй половины XVIII века: очерки истории общественного сознания (Москва: Новое литературное обозрение, 2017), 201-202. (Е. N. Marasinova, "Zakon" i "grazhdanin" v Rossii vtoroi poloviny XVIII veka: ocherki istorii obshchestvennogo soznaniia (Moscow: Novoe literaturnoe obozrenie, 2017), 201-202). Что в данном случае стало причиной самоубийства? Нищета? Тоска по жене? Помешательство? Вероятно, все вместе, что можно описать словом “отчаяние.”
} 
вторых, чтобы понять, не была ли женщина убита. Так, в 1764 г. в Валуйском уезде с пристрастием допрашивали 25-летнего казака Григория Савостьянова, чья жена Татьяна повесилась на пятой неделе после свадьбы. Григорий утверждал, что “с показанною женою прежде ссор и драк никогда не чинил и как удавилась, того не знает, и шуму, и крику ничево не слыхал,” однако его отправили в Белгородскую губернскую канцелярию, где после еще двух допросов с пристрастием он своих показаний не изменил, был доставлен назад и дело закрыли. ${ }^{92}$ Два года спустя в том же уезде также били плетьми и допрашивали однодворца Филиппа Колесникова, мужа повесившейся Пелагеи Колесниковой, признавшегося, что “жительство с нею имел порядочно и никогда ее не бивал, а только он, Филип, сего году в прошедшей зиме чинил побег однадворца Самсона Колесникова с невескою ево Дарьею, с которою жил блудно, и за то в Валуйской воеводской канцелярии наказаны батоги.” Поскольку за свой проступок Филипп уже был наказан, а ревность, меланхолию или тоску жены по поводу измены мужа поставить ему в вину было невозможно, он был освобожден, хотя выборному и велели “разведывать," не обнаружится ли чего-то “подозрительного." 93 Едва ли не единственный зафиксированный случай, когда муж, если и не чувствовал себя виноватым, то, по крайней мере, связывал самоубийство жены с рукоприкладством, имел место в Обоянском уезде в 1746 г., где однодворец Самойла Малыхин "ударил раз рукой по щеке, за то, что она, Меланья, не обстоятельно убравши.” Находясь, по-видимому, под впечатлением от случившегося, прибывшим на место происшествия десятскому и пятидесятскому он обмолвился, сказав: “мой грех," за что вместе со своим отцом был тут же избит палками. ${ }^{94}$ Посвоему уникальным можно счесть объяснение помещичьего крестьянина Можайского уезда Василия Петрова, утверждавшего, что его покончившая с собой в 1765 г. жена Арина “жила с ним не в согласии и ево, Василья, не любила, однакож он ее и за то, и ни за что не бивал, и никто ее, равно и он, Василей, не умерщвливал." 95

Мать удавившейся в 1764 г. жены однодворца Захара Глаголева утверждала, что зять ее дочь “всегда бивал тирански.” Тот в свою очередь показал, что “только до оного, как она удавилась, дни за три при посылке ее в поле для полония хлеба за ослушность вдарил четыре раза ладонью по щекам, а боле уже ничем не бил, и от чево оная удавилась, не знает.” Повальный обыск и тут ничего не дал и дело закрыли. ${ }^{96}$ “По закону и в любви под страхом бога своего” жил, по его уверению, со своей женой псковский посадский Семен Рошков и только “бил ее плетью и ударил только раз с полдесятого за продерзостье.” И, хотя у его удавившейся жены Федосьи при осмотре тела оказалось, что “спина избита с поясницы и до плеч до крови и с трупом поволокло, и в других местех бито и правое стегно избито ж и левое плечо и рука избита и синя и багрово," а двоюродный брат покойной обвинял Рошкова в том, что тот бил жену постоянно, хвалился этим, да еще и изменял ей с некоей крестьянкой Матреной, он был отпущен без всякого наказания ${ }^{97}$. Следы избиения были обнаружены и на теле повесившейся в Курском уезде жены однодворца Дмитрия Познякова, однако чиновники канцелярии, судя по всему, охотно поверили

\footnotetext{
${ }^{22}$ РГАДА, ф. 470, оп. 1, д. 1327, л. 1-20. (RGADA, f. 470, ор. 1, d. 1327, 1. 1-20).

93 Там же, д. 1529, л. 2-4. (Тam zhe. d. 1529, 1. 2-4).

${ }^{94}$ РГАДА, ф. 545, Обоянская воеводская канцелярия, оп. 1, д. 4442, л. 1-4. (Tam zhe, f. 545, Oboianskaia voevodskaia kantseliariia, op. 1, d. 4442, 1. 1-4).

95 Там же, ф. 533, Можайская воеводская канцелярия, оп. 1, д. 292, л. 3. (Tam zhe, f. 533, Mozhaiskaia voevodskaia kantseliariia, op. 1, d. 292, 1.3).

${ }^{96}$ Там же, д. 1654, л. 1-3. (Tam zhe, d. 1654, l. 1-3).

97 РГАДА, ф. 477, Гдовская воеводская канцелярия, оп. 1, д. 645, л. 2-5. (RGADA, f. 477, Gdovskaya voevodskaya kantseliaria, op. 1, d. 645, l. 2-5).
} 
ему и его братьям, утверждавшим, что покойная Аграфена “была в безумии - кричала по-собачьи, по-кошачьи и птичьими голосами." 98

В ряде случаев игнорирование чиновниками канцелярий, казалось бы, прямых указаний на факты насилия по отношению к женщинам было вызвано не только тем, что само оно воспринималось как норма, ${ }^{99}$ но и, либо попросту нежеланием заниматься долгим и малоперспективным расследованием, либо какими-то обстоятельствами коррупционного характера, остающимися за рамками архивных документов. Так, случай с самоубийством жены псковитянина Рошкова произошел в Гдове, где муж покойной был откупщиком питейных сборов и наверняка имел возможность воздействовать на следствие. В 1763 г. в Ливенском уезде был наказан батогами однодворец Иван Аширмин, утверждавший, что видел на теле своей повесившейся тетки “боевые знаки: левая щека вся изодрана, верхнея губа перервана, на шее рубец, да по тому признанию, спустя мало с левого плеча рубашки, усмотрел же боевые ж знаки, от чего значится синево.” Однако муж покойной однодворец Сила Семенихин и несколько допрошенных крестьян дружно утверждали, что никаких “боевых знаков” на теле не было. И, хотя вопреки установленным порядкам, “он, Сила, обще з братом своим родным Ильею, выкопав яму, и то мертвое жены своей тело, ни с чьяго позволения, но собою,.. в ту яму и зарыли без погребения,” а “пред Ливенскую канцелярию не привозил, и то с недознания ево, Силина, а не для какого закрывательства,” подозрений в сговоре у чиновников не возникло. Аширмин был наказан за ложный донос, ${ }^{100}$ но относительно низкий социальный статус однодворца Силы Семенихина никак не исключает того, что он обладал социальным или экономическим капиталом, позволявшим ему воздействовать и на свидетелей, и на ход следствия.

$$
\stackrel{*}{*} *
$$

Итак, введение в русскую судебную практику норм Артикула воинского означало криминализацию самоубийства, а также его секуляризацию, что выразилось в том числе и в, по крайней мере, частичном отстранении церкви от решения вопроса о форме захоронения самоубийц. При этом тот факт, что к концу века рассмотрение дел о самоубийствах оказывается в ведении полицейских, а не судебных органов, как представляется, можно рассматривать, как признак постепенной декриминализации самоубийства. Не случайно самоубийство отсутствует среди перечисляемых Уставом благочиния 1782 г. уголовных преступлений, которые в зависимости от степени тяжести должны были затем передаваться в суд, а в докладах петербургских губернаторов императрице оно фигурирует среди других “происшествий.” Стоит также отметить, что в изученных документах ни разу не упоминается о наказании,

\footnotetext{
98 РГАДА, ф. 520, Курская воеводская канцелярия, оп. 5, д. 368, л. 1-2. (RGADA, f. 520, Kurskaia voevodskaia kantseliariia, op. 5, d. 368, 1. 1-2).

${ }^{99}$ O семейном насилии в России XVIII в. и его восприятии см. М. Г. Муравьева, "Повседневные практики насилия: супружеское насилие в русских семьях XVIII в.," Бытовое насилие в истории российской повседневности (XI-XXI вв.), под ред. Н. Л. Пушкаревой и М. Г. Муравьевой. (СанктПетербург: Издательство Европейского университета в Санкт Петербурге, 2012), 52-105. (М. G. Murav'ieva, "Povsednevnye praktiki nasiliia: supruzheskoe nasilie v russkikh sem'iyakh XVIII v.," Bytovoe nasilie $v$ istorii rossiyskoi povsednevnosti (XI-XXI vv.), pod. red. N. L. Pushkarevoi i M. G. Murav'evoi (St. Petersburg: Izdatel'stvo Evropeiskogo universiteta v Sankt Peterburge, 2012), 52-105).

${ }^{100}$ РГАДА, ф. 523, Ливенская воеводская канцелярия, оп. 1, д. 667, л. 1-34. (RGADA, f. 523, Livenskaia voevodskaia kantseliariia, op. 1, d. 667, 1. 1-34).
} 
как предусмотрено Артикулом воинским, за попытки самоубийства оставшихся при этом в живых, хотя, возможно, эта норма применялась в отношении военных.

О реакции людей на самоубийство архивные документы сообщают крайне скупо. Крестьянка Марина Логинова, как упоминалось выше, увидев повесившуюся сестру “по той сестре сплакала и свету не увидала, и стала быть нечуственна," жена утопившегося майора Апухтина, по свидетельству его дворовых, узнав о смерти мужа, “взвыла и ударилась оземь.” ${ }^{\circ 1}$ В нескольких делах упоминается, что обнаружившие самоубийцу начинали кричать, с криком бежали к соседям, звали на помощь. Еще в нескольких случаях упоминается испытанный ими испуг, причем в одном случае речь идет о прислуживавшем в питейном доме подростке, обнаружившем повесившегося служителя этого заведения, а в двух других - о мужьях, нашедших покончивших с собою своих жен. Дворовый генерала Шепелева Сергей Лбов был так потрясен и напуган смертью своего господина, что убежал из дома, бродил где-то целые сутки и тем навлек на себя подозрения следователей. В принципе все эти реакции вполне естественны и не содержат в себе ничего специфического именно для XVIII века. Испуг свидетелей самоубийства мог быть вызван и самим видом смерти, и внезапностью случившегося, и страхом перед последствиями, опасением быть обвиненным в убийстве. В сущности, словом “испуг” люди того времени обозначали то, что в наше время назвали бы шоком. Однако, с чем связан сам факт того, что упоминания об эмоциональных реакциях людей на самоубийство столь редки?

Можно предположить, это связано с тем, что расследовавших эти дела чиновников подобные подробности не интересовали. Однако историки, работающие с судебноследственными документами этого периода, хорошо знают, что подследственные зачастую рассказывали о таких подробностях своей жизни, о которых их вовсе не спрашивали и которые не имели отношения к делу, а следователи аккуратно фиксировали их рассказы. На первый взгляд, это дает повод осторожно предположить, что, может быть, самоубийство, по крайней мере, в крестьянской среде, не воспринималось как нечто экстраординарное. В русском фольклоре и в древнерусской литературе описание самоубийства встречается крайне редко и, хотя в целом отношение к нему отрицательное, в былинах и повестях это в основном описания самоубийств героического характера. ${ }^{102}$ Между тем, в русской мифологии самоубийцы относятся к так называемым “заложным” покойникам, то есть умершим “неправильной” смертью, и с ними, как и у многих других народов, связано немало поверий, согласно которым душами самоубийц распоряжается нечистая сила, а сами они продолжают ходить среди живых, доживая положенный им срок. ${ }^{103}$ Однако следов проявления подобного восприятия в делопроизводственных источниках не прослеживается. Петербургские чиновники, принимавшие решение об отсылке тел самоубийц в Академию наук для упражнений в анатомии, вряд ли были атеистами, но они определенно не разделяли простонародных суеверий. Если за строчками документов и можно распознать какие-то эмоции, то разве что досаду на случившееся, искреннее недоумение по поводу поступка, совершенного близким или

${ }^{101}$ РГАДА, ф. 382, оп. 1, д. 38, л. 5об. (RGADA, f. 382, op. 1, d. 38, 1. 5ob.).

${ }^{102}$ Е. Н. Куницына, “Полемика о самоубийстве в топосе русской культуры," SuperInf.ru, дата обращения 6.5.2020, https://superinf.ru/view helpstud.php?id=4338. (E. N. Kunitsyna, "Polemika o samoubiistve v topose russkoi kul'tury," data obrashcheniia 6.5.2020, https://superinf.ru/view_helpstud.php?id=4338.

${ }^{103}$ См. Е. Е. Леквиевская, Мифы русского народа (Москва: Астрель, АСТ, 2000), 214-225. (Е. Е. Lekvievskaia, Mify russkogo naroda (Moscow: Astrel, AST, 2000), 214-225). 
просто знакомым человеком или, наоборот, если речь идет о больном человеке, то восприятие этого поступка как естественного. Скорее всего, мы все же имеем дело с ограниченностью информации доступных нам источников. Рассказ женщины, которую допрашивали в связи с кражей о том, что она “жила блудно” с каким-то солдатом, мог стать предметом отдельного расследования, в то время как эмоции не имели для следователей никакого значения, и можно было не утруждать себя их фиксацией в официальных документах.

Что касается причин самоубийств, то в этом отношении россияне XVIII века мало отличались от своих европейских современников, разве что список таких причин был чуть короче, а пьянство, если верить петербургским следователям последней четверти столетия, занимало в нем более заметное место. Петровские преобразования, несомненно, сделали русское общество более динамичным, открыв каналы социальной мобильности и возможности предпринимательской деятельности. Однако случаев, когда самоубийство мужчин связывалось с крушением надежд на обретение социального или экономического капитала, в изученных документах не обнаружено. Вряд ли, к примеру, к таковым можно отнести случай, когда 26 августа 1786 г. в Петербурге “в 1-й Адмиралтейской части в театральном корпусе по галереи в пустом покое петровской купец Ефимов на поясе обвесился. По изысканию открылось, что он, торговав, промотался и пред тем несколько дней пил." 104 Пожалуй, единственная выделяющаяся из общего ряда причина самоубийства, зафиксированная в документах, это не мужское, а женское самоубийство 1793 г.: “у камер-юнкера Жеребцова находившаяся в доме кормилицею отпущенная на волю от княгини Щербатовой дворовая женка того ж числа на чердаке удавилась. По исследованию частнаго пристава открылось, что она пред тем тосковала и что отняли от нее дитя, коего она кормила."105

С тоской, меланхолией, ипохондрией и “задумчивостью,” как и в Европе раннего Нового времени, связывали в России XVIII в. причину самоубийств, подразумевая под этим болезнь, ${ }^{106}$ которую в наше время называют депрессией и которая, в отличие от пьянства, служила смягчающим обстоятельством при решении вопроса о форме захоронения самоубийцы. Зарезавшийся в 1790 г. алмазных дел подмастерье Кудусков, “по объявлению домашних, накануне того дня был в великой задумчивости и в обращении с ними беспокоен и беспорядочен.” 107 Жена “Ораниенбаумскаго садоваго мастера Гомбеля Катерина Иванова дочь урожденная Гетте,” зарезавшаяся бритвой в 1792 г., была "в задумчивости и крайнем унынии о отрешении означеннаго мужа ее от должности." ${ }^{08}$ Чувства, которые испытывали люди, пребывавшие в тоске и меланхолии, можно обозначить словами “безысходность,” “отчаяние.” Именно это очевидно испытывал подканцелярист Александр Рубцов, с посмертного письма которого начинается эта статья. Но в христианской традиции отчаяние считалось грехом. Впасть или не впасть в отчаяние зависело от воли человека, в то время как болезнь была результатом воздействия внешних сил и, соответственно, смягчающим обстоятельством.

\footnotetext{
${ }^{104}$ РГАДА, ф. 16, оп. 1, д. 526, ч. 1, л. 255. (RGADA, f. 16, оp. 1, d. 526, ch. 1, l. 255).

${ }^{105}$ Там же, ч. 2, л. 246. (Tam zhe, ch. 2, 1. 246).

${ }^{106}$ См. Екатерина Махотина, "Меланхолия приходит в Россию. Монастыри как долгаузы в России в XVIII веке," Вивліоөика: E-Journal of Eighteenth-Century Russian Studies, vol. 7 (2019): 21-46. (Ekaterina Makhotina, "Melankholiia prikhodit v Rossiiu. Monastyri kak dolgauzy v Rossii v XVIII veke," Вивліоөика: ЕJournal of Eighteenth-Century Russian Studies, vol. 7 (2019): 21-46).

${ }^{107}$ РГАДА, ф. 16, оп. 1, д. 526, ч. 5, л. 207. (RGADA, f. 16, оp. 1, d. 526, ch. 5, l. 207).

${ }^{108}$ Там же, ч. 6, л. 335. (Tam zhe, ch. 6, 1. 335).
} 
Расследуя дела о самоубийствах, российские чиновники в целом придерживались нормы закона и при этом в основном действовали достаточно оперативно. Тот факт, что в провинции на места для освидетельствования покойников посылались, как правило, служащие самых низких рангов, было не результатом пренебрежительного отношения к подобным случаям, а скорее, следствием как скудости ресурсов, которыми обладали местные органы власти, так и того, что самоубийства не были чем-то экстраординарным, требовавшим особого внимания. В сущности, это была часть повседневной рутинной работы наряду со сбором податей, расследованием убийств, краж, бесчисленных дел о бесчестье, о беглых, падеже скота, отказе имений и всего прочего, чем занимались местные органы власти.

В целом на основании изученных источников можно сделать вывод, что, по сравнению с Европой раннего Нового времени, феномен самоубийства в России XVIII столетия не имел существенных, принципиальных отличий, ${ }^{109}$ однако особенности российской судебно-следственной системы делали это явление менее публичным, менее заметным и менее значимым для общественного сознания. Лишь к концу века, с увлечением образованной молодежи “Страданиями юного Вертера" Гете, с появлением самоубийц-интеллектуалов и проникновением в Россию “английской болезни” самоубийство начинает занимать в общественной повестке более значимое место.

\footnotetext{
${ }^{109}$ Стоит лишь заметить, что в России не были известны распространенные в Северной Германии и Голландии так называемые суицидальные убийства, когда человек совершал убийство с расчетом на то, что за это он будет казнен, но перед смертью успеет раскаяться и исповедоваться.
} 